\title{
Investigating the effects of employee empowerment on turnover intention in a mining organisation
}

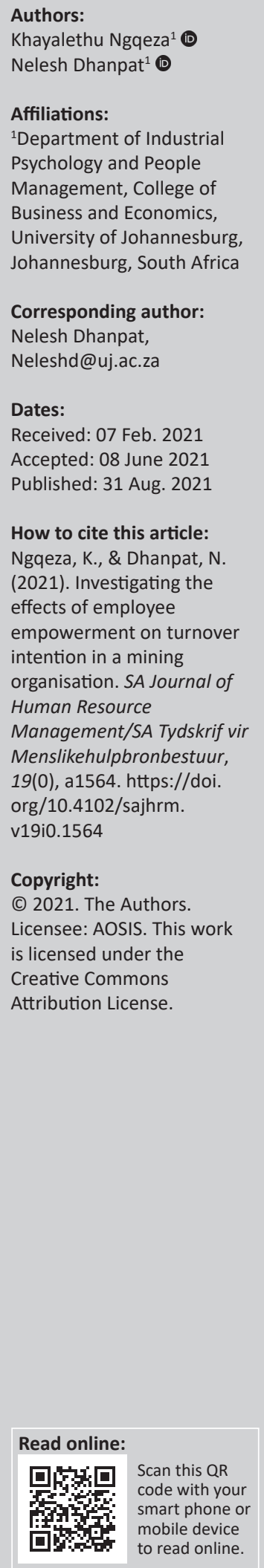

Orientation: Mining plays a significant role in the South African economy and is crucial for job creation opportunities. Mining organisations are plagued by various challenges, which include turnover intention.

Research purpose: The current study sought to establish whether employee empowerment (psychological and structural empowerment) predicts turnover intention in a mining organisation.

Research approach/design and method: The study followed a quantitative research approach and used a cross-sectional design. A non-probability sampling technique was used, and a purposive sampling method was selected. The sample comprised 371 mining employees $($ men $=276$; women $=95)$. Data were collected through pre-established measures, all of which reported acceptable Cronbach's alphas. Various statistical techniques were employed to address the main research objective.

Main findings: Employee empowerment negatively impacts turnover intention. The employees who perceived having informal power were more likely to consider leaving the organisation. Employees who perceived less formal power were more likely to consider leaving than the employees who perceived having formal power.

Practical/managerial implications: Recommendations are made to HR practitioners regarding employee empowerment of mining employees, which, when implemented, have the potential to reduce employee turnover intention.

Contribution/value-add: The results of this study provide a better understanding to human resource managers about the relationship between employee empowerment and turnover intention of mining personnel. This study contributed to theory, as some key findings are different from previous studies within the South African context.

Keywords: empowerment; structural empowerment; psychological empowerment; turnover; mining; mines.

\section{Introduction}

The mining industry is a key to the economy and the development of South Africa, as it employs a significant percentage of the South African population (Marais et al., 2018; Neingo \& Tholona, 2016). It is known that mining activities largely influence the socio-economic conditions of the people in mining communities (Kane-Berman, 2018) and do so by contributing towards the community's employment, education and increased infrastructure (Mancini \& Sala, 2018). According to Chaskalson (2016), South Africa is the largest platinum producer globally and accounts for $87 \%$ of the world's platinum-group metals. Since the 1880s, South Africa has extracted large quantities of gold. However, the interplay of gold prices and increased production costs has resulted in some mining operations' downsizing and others completely shutting down. This has slowed business outputs and consequently negatively affected the economy and the country's development (Marais et al., 2018). Mining remained one of the main drivers of the South African economy and accounted for approximately 8\% of the country's gross domestic product (GDP) in 2015 (Republic of South Africa, 2020).

\section{Background to the study}

Some mining operations experience difficulties in retaining employees because of various factors, such as treatment by supervisors and lack of career growth prospects (Brown, Susomrith, Sitlington, \& Scott, 2014). More so, business environments are characterised by fluctuating markets and 
organisational restructurings (Dhanpat \& Parumasur, 2014), and these events are likely to result in uncertainty within businesses (Buta \& Burciu, 2014). Organisational restructuring and downsizing have negative implications for mine employees who survive retrenchments in that it is expected of these remaining workers to increase their outputs to sustain business profits (Chen, Chen, Zhu, Qi, \& Long, 2015). The mining work environment is exacerbated by dynamic global trends, technological advancement and changing environmental regulations that seem to expose mine employees to occupational stress (Mościcka-Teske, SadłowskaWrzesińska, Najder, \& Butlewski, 2019). In addition to this, mining is risky to the health and safety of employees (Amponsah-Tawiah, Leka, Jain, Hollis, \& Cox, 2013; Kasap, 2011; Paul \& Maiti, 2007). Historically, in South Africa, men came to work in the mines to provide for their families; many were injured or died in the line of duty and never returned to their families (Masia \& Pienaar, 2011). Some employees travel long distances to the workplace and are expected to meet steep production targets to qualify for production bonuses (Chimamise et al., 2013; Mclean, 2012). It is suggested that these circumstances take a toll on employees, and support from the managers is necessary. Therefore, based on the work environment at mines and employees' perceiving that they are not treated well by their managers, turnover intention may arise (Amponsah-Tawiah, Ntow, \& Mensah, 2016).

The study's objective was to establish if employee empowerment (psychological and structural empowerment) predicts turnover intention in a mining company. The subobjectives of the study are to establish if employee empowerment predicts turnover intention, to establish a relationship between employee empowerment and turnover intention and to elicit whether there are significant differences in the views regarding employee empowerment and turnover intention of employees along the lines of biographical characteristics (age, gender, tenure and work experience). There is a paucity of research regarding the relationship between employee empowerment and turnover intention within the mining industry. This study sought to close the gap regarding this phenomenon.

\section{Employee empowerment}

The notion of employee empowerment can be derived from concepts of participative management, industrial democracy and job enrichment (Spreitzer, De Janasz, \& Quinn, 1999). To empower implies giving power to someone else (Conger \& Kanungo, 1988). It can be suggested that if Person B is empowered, dependency on Person A may cease (Kanter, 1993). Employee empowerment enables employees to make decisions and take risks to try something new (Spreitzer \& Doneson, 2005). The current study will mainly look into two types of employee empowerment: structural and psychological empowerment.

\section{Structural empowerment}

Kanter (1977, 1993) defined structural empowerment in relation to the actions an organisation takes to equip the employee. Structural empowerment refers to the availability of opportunities, information, resources and support for the employees in the workplace (Kanter, 1993). These avenues are accessed through formal job characteristics (formal power) and informal job characteristics, such as alliances with superiors, peers and subordinates (informal power; Kanter, 1993). Opportunity refers to future prospects for promotion or acquiring new skills crucial for successful performance of the job and an increase in rewards (Kanter, 1993). Information refers to the sharing of important information by the organisation with employees. This information may pertain to productivity, costs, financial performance (Seibert, Silver, \& Randolph, 2004), expertise, data and technical knowledge (Kanter, 1977, 1993). Access to resources refers to the timeous provision of equipment, material and human resources in an endeavour to achieve business goals (Kanter, 1977, 1993; Laschinger, 2012). Support means having the necessary help or advice to solve work-related problems (Kanter, 1977, 1993; Laschinger, 2012).

\section{Psychological empowerment}

Psychological empowerment refers to increased intrinsic task motivation emanating from four perceptions: meaningfulness, competence, choice and sense of impact (Thomas \& Veldhouse, 1990). Borrowing from Thomas and Veldhouse's definition, Spreitzer (1995) defined psychological empowerment as 'a motivational construct manifested from four cognitions: meaning, competence, self-determination, and impact' (p. 1444). Meaning refers to the employee's view that his or her work is important (Quinn \& Spreitzer, 1997). Competence refers to the employees' perceptions regarding their capability to perform such tasks (Menon \& Vos, 2007; Quinn \& Spreitzer, 1997). Self-determination (choice) is the liberty and the autonomy that employees may have to perform their daily tasks (Quinn \& Spreitzer, 1997; Seibert et al., 2004). Impact is the degree to which the behaviour of employees determines whether they become successful in their areas of responsibility (Thomas \& Veldhouse, 1990).

\section{Antecedents of employee empowerment}

A conducive environment for employee empowerment is characterised by clear articulation of organisational vision, openness, teamwork and a sense of support by managers (Quinn \& Spreitzer, 1997). Supervisory style (e.g. authoritarian and lack of reason for actions), reward systems (e.g. low incentive value of rewards and lack of competence-based rewards), job design (e.g. lack of role clarity, training and technical support) and organisational factors (e.g. competitive pressures and poor communications) serve as determinants of employee empowerment (Conger \& Kanungo, 1988). Organisational support and clear understanding of roles by employees seem to predict psychological empowerment, which may eventually lead to productive, creative behaviour (Kang et al., 2020). Employees with a high power distance culture may perceive higher psychological and structural empowerment in their work. In contrast, employees with 
individualistic cultures may perceive lower structural and psychological empowerment, although they are exposed to the same empowering practices (Jiang, Wang, Chu, \& Zheng, 2019).

\section{Employee empowerment and organisational outcomes}

Empowerment initiatives such as career development may improve the relationship between managers and subordinates (Ertürk \& Vurgun, 2015). Highly empowered employees are likely to perform better because of better insight into their work environment (Mahmood \& Sahar, 2017). Employee empowerment leads to job engagement (Jiang et al., 2019) and job satisfaction (Choi, Goh, Adam, \& Tan, 2016). Paynton (2008) found that nurses make use of informal power to achieve their objectives. Amongst other things, they utilise their expertise to influence the physicians to make decisions that they deem fit for patients' specific medical conditions. Informal power helped immigrant nurses to learn a new language (Eriksson \& Engstrom, 2018). At the same time, perceptions of formal and informal power may influence perceived access to organisational empowerment structures. In combination, formal power, informal power and access to empowerment structures predict the extent of involvement in work-related decisions (Laschinger, Sabiston, \& Kutszcher, 1997). Access to organisational empowerment structures is associated with higher formal and informal power (Laschinger et al., 1997).

Empowerment also brings about job enrichment and consequently improves retention (Mahmood \& Sahar, 2017). Empowered employees tend to remain with their current employer during difficult and challenging times (Bester, Stander, \& Van Zyl, 2015). It is suggested that empowering managerial practices may lead to an energetic and resilient workforce (Van Schalkwyk, Du Toit, Bothma, \& Rothmann, 2010). Empowered employees become innovative, which eventually assists in bringing about customised solutions for an organisation's clients (Kostopoulos, 2019).

Empowered employees have the responsibility to make decisions about their work and how it is performed (Motebele \& Mbohwa, 2013). They tend to be transformational in their leadership approach and tend to make significant changes in their work environment (Quinn \& Spreitzer, 1997; Spreitzer et al., 1999). Both psychological and structural empowerments are the vital antecedents of employees' commitment (Aggarwal, Dhaliwal, \& Nobi, 2018). When employees perceive that they are psychologically empowered, they may engage in citizenship behaviours, which may eventually decrease their turnover intention (Bester et al., 2015; Fasanmi \& Ago-Iwoye, 2018; Rogers, 2016).

\section{Turnover intention}

Turnover intention is a sign that the employee intends to leave the organisation or indicate the intention to secure another job (Brien, Thomas, \& Hussein, 2015; Ferede et al.,
2018; Jung, 2014; Meyer \& Tett, 1993; Vandenberg \& Scarpello, 1990). The concept of turnover intention refers to an employee's deliberate decision to leave the current employer (Meyer \& Tett, 1993) and look for better opportunities (Brewer \& Kovner, 2014).

\section{Turnover intention and previous research}

Investigation on turnover intention is imperative as it serves as a dipstick of the organisation's well-being (Jung, 2014). Intention to quit the organisation can be attributed to workrelated factors such as managerial practices (e.g. remuneration strategy, supervision style) and different organisational characteristics (Kim \& Fernandez, 2017). Turnover intention may cause employees to be less committed to their work and negatively impact their outputs (De Simone, Planta, \& Cicotto, 2018). Employee retention is key for survival in a competitive labour market (Rogers, 2016). Lu, Sun and Du (2016) found that highly employable workers seem to have less turnover intention, even when there are fewer career development opportunities within their organisation. A possible cause of this behaviour is the recent uncertainty in the labour market. The organisation in which the study was conducted had a good reputation; this may have contributed to why the highly employable employees did not intend to leave the organisation. Employees who intend to leave the organisation to become a liability to the organisation (Jung, 2014; Xiong \& Wen, 2020) because their organisational commitment tends to decrease (Xiong \& Wen, 2020). In light of this, organisations may prefer employees to leave rather than stay whilst they are less committed. Organisational initiatives that seek to address turnover intention may lower the costs associated with the demand and supply of personnel (Jung, 2014). Managers with long job tenure but lacking upward mobility opportunities are more likely to resign than those who have experienced great career success. At the same time, managers with long job tenure and high responsibility are more likely to leave than those with lower responsibility (Taylor, Audia, \& Gupta, 1996). Within a mining setting, it is to our knowledge that such research has not yet been established.

\section{Research design}

This cross-sectional study followed a quantitative research approach. Quantitative research establishes relationships between variables appropriate for large samples and makes inferences to test existing theory (Saunders, Lewis, \& Thornhill, 2016).

\section{Research procedure}

The current study was conducted in a single mining organisation based in Gauteng province in South Africa. Data were collected through the use of a survey after ethical clearance was obtained from the University of Johannesburg. Data collection took approximately 3 months. The questionnaires were paper-based, and envelopes were 
provided in which the questionnaires were sealed. The questionnaires comprised four sections, namely, biographical information and the three scales listed below (see Measuring Instruments). Permission was requested from the employer to contact the selected sample. Questionnaires were distributed to the respondents for completion and then returned into a secured box at the training centre reception area. After the responses were received, they were captured on a Microsoft Excel spreadsheet and then imported directly into IBM SPSS (Version 25.0) for statistical analysis.

\section{Research participants}

Participants were selected from employees who could read and understand English across all occupations in the mine. Purposive sampling (a non-probability technique) requires researchers to use their judgement to select cases that will assist in answering the research questions, which is why it is often referred to as judgemental sampling. The current study used purposive sampling to enable the researcher to target respondents who could read and understand English. The problem with purposive sampling is its inability to provide a statistically representative sample (Saunders et al., 2016). The research was conducted on a final sample of 371 employees. A biographical questionnaire was used to collect information about the respondents, such as gender, age, education, race, home language, work experience and tenure.

The sample comprised of $74.40 \%$ men $(n=276)$ and $25.60 \%$ women $(n=95)$. In terms of age, $49.86 \%$ of employees $(n=182)$ fell into the category 30-39 years old, followed by $23.83 \%$ ( $n=87$ ) who were 40-49 years old; 20-29 year-olds represented $15.89 \%(n=58), 9.59 \%$ were in the category $50-59$ years old $(n=0.55)$ and the least represented were the 60-65 years old $(n=2)$. Most respondents belonged to the Black race group $(n=353 ; 95.1 \%)$. Most respondents were employed as operators, general workers and trainees $(n=186 ; 51.81 \%)$. Most respondents were employed between 3 and 6 years $(n=149$; $40.93 \%$ ), whilst only $9.06 \%$ of employees $(n=33)$ had been employed at the company for more than 16 years at the mine.

\section{Measuring instruments}

The following measures were used: the Psychological Empowerment Scale (PES; Spreitzer, 1995), Structural Empowerment Scale (SES; Laschinger, Finegan, Shamian, \& Wilk, 2001) and the Turnover Intention Scale (TIS; Sjoberg \& Sverke, 2000).

\section{Structural empowerment scale}

The SES is a 19-item measure of six dimensions: opportunity, support, resources, information, informal power and formal power (Laschinger et al., 2001). In the current study, the scale was adapted for the mining industry. The items are scored on a 5-point Likert-type scale ranging from 1 (none) to 5 (a lot) and include statements such as 'The chance to gain new skills and knowledge on the job'. Smith, Capitulo, Quinn Griffin and Fitzpatrick (2012) reported acceptable Cronbach's alpha coefficients for the six dimensions: information (0.80), opportunity (0.76), support (0.92), formal power (0.93), resources (0.81) and informal power (0.87).

\section{Psychological empowerment scale}

The PES (Spreitzer, 1995) is a 12-item measure of four dimensions: meaning, competence, self-determination and impact. The items are scored on a 7-point Likert-type scale ranging from 1 (strongly disagree) to 7 (strongly agree) and include statements such as 'I can decide on my own how to go about doing my work'. Stander and Rothman (2010) reported acceptable Cronbach's alpha coefficients for the four dimensions: meaning (0.83), competence (0.74), selfdetermination (0.76) and impact (0.77).

\section{Turnover intention scale}

The TIS is a three-item measure (Sjoberg \& Sverke, 1996), scored on a 5-point Likert-type scale ranging from 1 (strongly disagree) to 5 (strongly agree) and includes statements such as 'If I was completely free to choose, I would leave this job'. Bester et al. (2015) reported an acceptable Cronbach's alpha coefficient of 0.83 .

\section{Statistical analysis}

The data were analysed through Statistical Package for the Social Sciences. In the first step of statistical analysis, data were checked for a range of responses, typing mistakes, incomplete questionnaires and statistic outliers. Statistical analysis techniques included descriptive statistics, inferential statistics, regression analysis, reliability and validity. Descriptive statistics enabled the researcher to present the data in a meaningful way. Measures of central tendency, measures of spread (Saunders et al., 2016), skewness and kurtosis values were used to check the normality of data (Pallant, 2016). Previous studies have validated the measures used in the current study. Stander and Rothman (2009) conducted a confirmatory factor analysis (CFA), which revealed a strong factor-analytic fit of the PES to other samples in South Africa.

Spearman's rank correlation was utilised to explore the strength and the direction of the relationship between employee empowerment and turnover intention. The logistic regression was used, because the data were skewed and the dependent variable was categorical: intention to leave (coded 0) and intention to stay (coded 1). Logistic regression was used to forecast whether employees belonged to the category 'intention to leave' or 'intention to stay' (Pallant, 2016). An independentsamples $t$-test was conducted to compare the scores for structural empowerment, psychological empowerment and turnover intention for males and females (Pallant, 2016).

\section{Ethical considerations}

Ethical clearance was obtained from the Department of Industrial Psychology and People Management research ethics committee. The ethics committee of the University of 
Johannesburg [ethical clearance code, IPPM-2019-401(M)] and the mining organisation in question approved the study procedures before the study commenced. The researcher signed confidentiality declarations to ensure the anonymity of the participating mine. The respondents were protected from emotional and psychological harm and embarrassment. Hard copies of the questionnaire will be securely stored for a period of 5 years.

\section{Results}

\section{Descriptive statistics}

The descriptive analysis for structural empowerment, psychological empowerment and turnover intention is presented (Table 1). The mean scores for the items within the structural empowerment sub-dimensions ranged from 3.4 to 3.74 . This may indicate that the employees in this study perceived that they did receive some structural empowerment in the workplace. Acceptable Cronbach's alpha coefficient values were achieved and ranged from 0.64 to 0.83 , suggesting internal consistency. Acceptable Cronbach's alpha coefficient values of 0.64 were derived. Opportunity obtained a value is under 0.70 , it was essential to assess the mean inter-item correlations to confirm internal consistency. According to Pallant (2010), measures that have a small number of items (under 10) are likely to yield lower reliability scores. Upon inspection of the mean interitem correlation, the value achieved was 0.37 , below the cutoff point of 0.40 . The mean scores for the items within the psychological empowerment sub-dimensions ranged from 5.04 to 6.27 . This may indicate that the employees in this study perceived that they are psychologically empowered in the workplace. Acceptable Cronbach's alpha coefficient values were achieved and ranged from 0.79 to 0.88 , suggesting internal consistency. The mean scores for the items within the TIS ranged from 3.50 to 3.78 , with an average mean value of 3.62. This suggests that employees disagreed slightly that they intended to leave the company. An acceptable Cronbach's alpha coefficient value of 0.86 was reported, suggesting internal consistency.

TABLE 1: Descriptive analysis for structural empowerment, psychological empowerment and turnover intention.

\begin{tabular}{lcccccc}
\hline Dimension & Mean & $\boldsymbol{A}$ & Std. Dev. & Var. & Skew. & Kurt. \\
\hline $\begin{array}{l}\text { Structural } \\
\text { empowerment }\end{array}$ & & & & & & \\
Opportunity & 3.74 & 0.64 & 0.91 & 0.82 & -0.81 & 0.552 \\
Information & 3.57 & 0.79 & 0.98 & 0.96 & -0.47 & -0.08 \\
Support & 3.47 & 0.83 & 1.01 & 1.02 & -0.55 & -0.14 \\
Resources & 3.52 & 0.77 & 0.95 & 0.908 & -0.37 & -0.53 \\
Informal power & 3.54 & 0.64 & 0.86 & 0.74 & -0.49 & -0.08 \\
Formal power & 3.40 & 0.73 & 1.01 & 1.01 & -0.38 & -0.51 \\
Psychological & & & & & & \\
empowerment & & & & & & \\
Meaning & 6.19 & 0.88 & 1.02 & 1.04 & -2.25 & 6.7 \\
Competence & 6.27 & 0.79 & 0.86 & 0.74 & -2.6 & 10.21 \\
Self-determination & 5.04 & 0.85 & 1.49 & 2.23 & -0.86 & 0.13 \\
Impact & 5.06 & 0.85 & 1.44 & 2.08 & -0.91 & 0.308 \\
Turnover intention & 3.62 & 0.86 & 0.50 & 0.25 & -1.13 & 3.42 \\
\hline
\end{tabular}

Std. Dev., standard deviation; Var., variance; Skew., skewness; Kurt., kurtosis.

\section{Logistic regression}

A direct logistic regression analysis was employed to assess the impact of employees' psychological empowerment and structural empowerment on turnover intention. The model contained four independent variables for psychological empowerment (viz. meaning, competence, self-determination and impact) and six independent variables for structural empowerment (viz. opportunity, information, support, resources, informal power and formal power). The final model contained three independent variables relating to psychological and structural empowerment (formal power, informal power and meaning), which were statistically significant, $\mathrm{X}^{2}(3, n=359)=95.7 \%, p<0.001$. This indicates the model distinguished between participants who intended to leave the organisation and those who intended to stay.

The Hosmer-Lemeshow test was employed to confirm the goodness of fit. A significance value greater than 0.05 indicates the model distinguished between participants who intended to leave the organisation and those who intended to stay. The chi-square value for the Hosmer-Lemeshow test was 8.873 , with a significance level of 0.353 . According to Pallant (2016), a value greater than 0.05 suggests support for the model.

The Cox and Snell and Nagelkerke $R$-square values were calculated. The model explained between $8.88 \%$ (Cox and Snell $R$-square) and $11.80 \%$ (Nagelkerke $R$-square) of the variance in employee empowerment and turnover intention. The results are represented (Table 2).

The model correctly classified $63 \%$ of the cases, which was an improvement over the $51.5 \%$ in the model without the predictors (see Table 2). In this instance, it is evident that the model correctly classified $59.2 \%$ of people thinking of leaving (also to be found in Table 2).

From the original 10 independent variables, only three contributed significantly to the model (Table 3$)$. These variables included informal power $(B=0.414)$, meaning $(B=-0.296)$ and formal power $(B=-0.639)$. The strongest predictor of turnover intention was assessed using the odds ratio. Pallant (2016) suggested that those values should be inverted for odds ratios that scored less than 1 (1 divided by the value) to assist with interpretation. In this case, formal power and meaning achieved values less

TABLE 2: Classification table for turnover intention.

\begin{tabular}{|c|c|c|c|}
\hline \multirow[t]{3}{*}{ Observed } & \multicolumn{3}{|c|}{ Predicted } \\
\hline & \multicolumn{2}{|c|}{ TO12 } & \multirow{2}{*}{$\begin{array}{c}\text { Percentage } \\
\text { correct }\end{array}$} \\
\hline & $\begin{array}{l}\text { Not thinking of } \\
\text { leaving }\end{array}$ & $\begin{array}{l}\text { Thinking of } \\
\text { leaving }\end{array}$ & \\
\hline \multicolumn{4}{|l|}{ Step 1} \\
\hline \multicolumn{4}{|l|}{ TOI2 } \\
\hline Not thinking of leaving & 123 & 62 & 66.5 \\
\hline Thinking of leaving & 71 & 103 & 59.2 \\
\hline Overall percentage & - & - & 63.0 \\
\hline
\end{tabular}

TOI, Turnover intention. 
than 1, and the odd ratios are hence inverted. In doing so, formal power obtained an odds ratio of 1.893, suggesting that employees who perceive less formal power are almost 1.9 times more likely to consider leaving than the employees who perceived having formal power, controlling other factors in the model. This was followed by informal power, as this recorded an odds ratio of 1.512 . Informal power achieved a positive beta value. In this case, employees who perceived having an increase in informal power were 1.5 times more likely to consider leaving than those who did not perceive that they had informal power, controlling all other factors in the model. According to Pallant (2016), a negative beta value suggests that an increase in the independent variable score will decrease the dependent variable's probability (turnover intention). Meaning obtained an odds ratio of 1.34, which suggests that employees who perceived less meaning in their work were 1.34 times likely to think about leaving the organisation when compared to the employees who perceived meaning in their job, controlling other factors in the model.

\section{Correlation analysis - Structural empowerment, psychological empowerment and turnover intention}

A weak, negative correlation between structural empowerment and turnover intention (rho $=-0.23, n=366, p<0.01$ ) with lower levels of structural empowerment associated with increased turnover intention is revealed (Table 4). Hence, a negative correlation exists. There was a weak, negative

TABLE 3: Logistic regression predicting turnover intention by employee empowerment.

\begin{tabular}{lcccccccc}
\hline Variable & B & $S E$ & Wald & $d f$ & Sig. & $\operatorname{Exp}(\boldsymbol{B})$ & $\begin{array}{c}\text { 95\% confidence } \\
\text { interval for } \operatorname{EXP}(\boldsymbol{B})\end{array}$ \\
\hline SE_IP & 0.414 & 0.161 & 6.606 & 1 & 0.010 & 1.512 & 1.103 & 2.073 \\
SE_FP & -0.639 & 0.143 & 19.973 & 1 & 0.000 & 0.528 & 0.399 & 0.698 \\
PE Meaning & -0.296 & 0.119 & 6.240 & 1 & 0.012 & 0.744 & 0.589 & 0.698 \\
Constant & 2.486 & 0.805 & 9.551 & 1 & 0.002 & 12.019 & - & - \\
\hline
\end{tabular}

$B$, beta; SE, standard error; df, degrees of freedom; Sig., significant; SE IP, structura empowerment informal power; SE FP, structural empowerment formal power; $P E$, psychological empowerment.

$p<0.05$.

TABLE 4: Spearman's rank correlation coefficient of structural empowerment, psychological empowerment and turnover intention.

\begin{tabular}{lccc}
\hline Variable & $\begin{array}{c}\text { Turnover } \\
\text { intention }\end{array}$ & $\begin{array}{c}\text { Psychological } \\
\text { empowerment }\end{array}$ & $\begin{array}{c}\text { Structural } \\
\text { empowerment }\end{array}$ \\
\hline Spearman's rho & & & \\
Turnover intention & 1.00 & $-0.15^{* *}$ & $-0.23^{* *}$ \\
$\quad$ Correlation Coefficient & - & 0.00 & 0.00 \\
Sig. (2-tailed) & 368 & 368 & 366 \\
$N$ & & & \\
Psychological empowerment & $0.15^{* *}$ & 1.00 & $0.48^{* *}$ \\
$\quad$ Correlation Coefficient & 0.00 & - & 0.00 \\
Sig. (2-tailed) & 368 & 372 & 369 \\
$n$ & & & 1.00 \\
Structural Empowerment & $-0.22^{* *}$ & $0.48^{* *}$ & - \\
$\quad$ Correlation Coefficient & 0.00 & 0.00 & 369 \\
Sig. (2-tailed) & 366 & 369 & \\
$n$ & & &
\end{tabular}

$* *, p<0.01$ level. correlation between psychological empowerment and turnover intention (rho $=-0.15, n=368, p<0.01$ ), with lower levels of psychological empowerment associated with increased turnover intention. Hence, a negative correlation exists. A positive correlation was established between structural empowerment and psychological empowerment (rho $=0.48, n=369, p<0.01$ ), with higher levels of structural empowerment leading to psychological empowerment.

\section{Spearman's rank correlation coefficient work experience, structural empowerment, psychological empowerment and turnover intention}

Only the correlation between work experience and psychological experience was significant (Table 5). There was a weak, positive correlation between work experience and psychological empowerment ( rho $=0.14, n=365, p<0.01$ ). Employees with longer work experience were associated with higher levels of psychological empowerment.

\section{Independent samples $t$-test: Gender on structural empowerment, psychological empowerment and turnover intention}

An independent samples $t$-test was conducted to compare the scores for structural empowerment, psychological empowerment and turnover intention for males and females. This also addresses the sub-research question that sought to elicit significant differences in the views regarding employee empowerment and turnover intention of employees varying in biographical details. It is evident that there was no significant difference in the scores for males $(M=3.58$; standard deviation $[\mathrm{SD}]=0.72)$ and females $(M=3.43 ; \mathrm{SD}=0.68)$ regarding structural empowerment, $t(365)=1.78, p=0.075$ (Table 6 and Table 7). There was a significant difference in the scores for males $(M=5.73$;

TABLE 5: Spearman's rank correlation coefficient of tenure on structural empowerment, psychological empowerment and turnover intention.

\begin{tabular}{lccc}
\hline Variable & $\begin{array}{c}\text { Psychological } \\
\text { empowerment }\end{array}$ & $\begin{array}{c}\text { Structural } \\
\text { empowerment }\end{array}$ & $\begin{array}{c}\text { Turnover } \\
\text { intention }\end{array}$ \\
\hline Spearman's rho & & & \\
How many years' work & & & \\
experience do you have? & $0.140^{* *}$ & 0.058 & -0.076 \\
$\quad$ Correlation Coefficient & 0.007 & 0.266 & 0.151 \\
Sig. (2-tailed) & 365 & 364 & 362 \\
$n$ & & &
\end{tabular}

$* *, p<0.01$

TABLE 6: Spearman's rank correlation coefficient of work experience on structural empowerment, psychological empowerment and turnover intention.

\begin{tabular}{llcccc}
\hline Variables & Category & $\boldsymbol{n}$ & Mean & Std. deviation & Std. error mean \\
\hline $\begin{array}{l}\text { Psychological } \\
\text { empowerment }\end{array}$ & Male & 275 & 5.72 & 0.85 & 0.05 \\
& Female & 95 & 5.44 & 0.96 & 0.10 \\
$\begin{array}{l}\text { Structural } \\
\text { empowerment }\end{array}$ & Male & 273 & 3.58 & 0.72 & 0.04 \\
& Female & 94 & 3.43 & 0.68 & 0.07 \\
$\begin{array}{l}\text { Turnover } \\
\text { intention }\end{array}$ & Male & 272 & 3.60 & 1.88 & 0.11 \\
& Female & 94 & 3.70 & 1.97 & 0.20 \\
\hline
\end{tabular}


TABLE 7: Independent-samples $t$-test: Gender on structural empowerment, psychological empowerment and turnover intention.

\begin{tabular}{|c|c|c|c|c|c|c|c|c|c|}
\hline \multirow[t]{2}{*}{ Variable } & \multirow{2}{*}{$\begin{array}{c}\begin{array}{c}\text { Levene's test for } \\
\text { equality of variances }\end{array} \\
F\end{array}$} & \multirow[t]{2}{*}{ Sig. } & \multirow{2}{*}{$\begin{array}{c}t \text {-test for equality } \\
\text { of means }\end{array}$} & \multirow[t]{2}{*}{ df } & \multirow[t]{2}{*}{ Sig. (2-tailed) } & \multirow[t]{2}{*}{$\begin{array}{c}\text { Mean } \\
\text { difference }\end{array}$} & \multirow[t]{2}{*}{$\begin{array}{l}\text { Std. error } \\
\text { difference }\end{array}$} & \multicolumn{2}{|c|}{$\begin{array}{l}\text { 95\% confidence interval of the } \\
\text { difference }\end{array}$} \\
\hline & & & & & & & & Lower & Upper \\
\hline \multicolumn{10}{|c|}{ Psychological empowerment } \\
\hline Equal variances assumed & 3.497 & 0.06 & 2.65 & 368.00 & 0.008 & 0.28 & 0.10 & 0.07 & 0.48 \\
\hline \multicolumn{10}{|l|}{ Structural empowerment } \\
\hline Equal variances assumed & 0.007 & 0.93 & 1.78 & 365.00 & 0.075 & 0.15 & 0.09 & -0.02 & 0.32 \\
\hline \multicolumn{10}{|l|}{ Turnover intention } \\
\hline Equal variances assumed & 0.069 & 0.79 & -0.42 & 364.00 & 0.675 & -0.10 & 0.23 & -0.54 & 0.35 \\
\hline
\end{tabular}

$\mathrm{SD}=0.85)$ and females $(M=5.44 ; \mathrm{SD}=0.96)$ regarding psychological empowerment, $t(368)=2.65, p=0.075$. A medium effect size of 0.30 was computed. There was no significant difference in the scores for males $(M=3.60$; $\mathrm{SD}=1.88)$ and females $(M=3.70 ; \mathrm{SD}=1.97)$ regarding turnover intention, $t(364)=-0.42, p=0.675$.

\section{Discussion}

The current study sought to establish if employee empowerment (psychological and structural empowerment) predicts turnover intention in a mining organisation. The study further sets out to establish a relationship between employee empowerment and turnover intention and elicits whether there are significant differences in employee empowerment and turnover intention along the lines of biographical characteristics (age, gender, tenure and work experience).

\section{Structural empowerment and turnover intention}

The mean values for all the structural empowerment dimensions ranged between 3.40 and 3.74, suggesting that the respondents perceived some access to all the structural empowerment avenues. However, none of the structural empowerment dimensions (i.e. opportunity, information, support and resources) were statistically significant, which means that none predicted turnover intention. This is intriguing, as no previous studies have come to the same conclusion. For example, Nie, Lamsa and Pucetaite (2018) found that equal career opportunities across all genders may prevent turnover intention of female employees. The organisation that embraces information stands a better chance of being responsive to dynamic business needs (Choo, 1996). When resources are accessible to the employees, this may lead to employee well-being, improved performance (Nielsen, Nielsen, Ogbonnaya, \& Känsälä, 2017) and lower stress levels (Yaldiz, Truxillo, Bodner, \& Hammer, 2020). Caring and supportive supervisors and team members become the true ambassadors of the organisation, and because of them, employees tend to see the organisation in a good light (Valcour et al., 2011). This suggests that although the employees in this organisation had some access to the empowerment avenues, they may not have been accessible enough to cause the intention to stay.

The results of the study revealed that formal power (odds ratio $=1.89$ ) was the strongest predictor of turnover intention. This suggests that employees who perceived an increase in formal power were 1.89 times likely not to leave the organisation. Formal power enables the employees to make decisions and be innovative and flexible about their jobs (Laschinger, 2012), which can help them be in charge of their outcomes. Access to formal power is thought to be instrumental in improving organisational performance in that it enables the employees to be responsive to changing business needs (Young-Hyman, 2017). Mine employees who perceived formal power were likely to feel good about the opportunity to contribute to the business, hence the intention to stay.

Similarly, informal power recorded an odds ratio of 1.512 . This shows that employees who perceived informal power were approximately one and a half times more likely to think of leaving the organisation. One would have expected that employees who perceived informal power would not intend leaving the organisation. In contrast to formal power, informal (personal) power does not depend on one's formal position but can be attributed to the individual's unique characteristics such as expertise, respect and so forth (Van Zyl, 2016). According to Kanter (1993), access to resources, information, support and knowledge can be accessed through both formal (formal power) and informal mechanisms (informal power). Considering this, it is expected that the employees who perceived having informal power would have greater access to empowerment avenues. The possible explanation is that in this particular organisation, one does not necessarily require informal power to have access to these avenues, as they are available to all. Employees with informal power are often asked by colleagues and managers for assistance (Laschinger, 2012). This may have happened in this organisation, but these employees may have perceived the extra tasks as a burden rather than informal power, mainly because the mining environment is characterised by hard labour (Chimamise et al., 2013; Mclean, 2012). In an industry in which hard labour is inherent, these extra tasks may have exacerbated these employees' already demanding work conditions. In an endeavour to save themselves from trouble that can be associated with the act of denying such requests, they may have complied, even if they were not happy about it. Thus, employees who possess informal power are more likely to think of leaving the organisation.

\section{Psychological empowerment and turnover intention}

Out of the four psychological empowerment dimensions (viz. meaning, competence, self-determination and impact), only meaning was statistically significant. Previous studies 
have not reported on whether competence, self-determination or impact can predict turnover intention. For example, Mikuljevi (2013) found that competent employees become a valuable asset and competitive advantage of an organisation. They provide an impulse to the business and play a vital role in the achievement of organisational goals. At the same time, supervisors with supervisory competency skills become effective in managing the workforce (Vijayabanu \& Therasa, 2016). Employees who are self-determined tend to be engaged in their jobs (Parker, Jimmieson, \& Amiot, 2010). Looking at the average mean values of these three dimensions (competence, self-determination and impact), it is evident that, to some extent, the employees in this organisation perceive themselves to be competent, having selfdetermination and making a significant contribution towards the achievement of business objectives (impact). However, these dimensions did not predict turnover intention.

Meaning obtained an odds ratio of 1.34, which suggests that employees who perceive less meaning in their work are 1.34 times likely to think of leaving the organisation compared to the employees who do not find meaning in their job. According to Schnell, Höge and Pollet (2013), the interaction between the supervisor and team members is a key in influencing work meaningfulness. These employees may have perceived less meaning in their jobs because of a lack of healthy interaction with their supervisors, hence the intention to quit. In light of this, they may not have seen the importance of pursuing their current jobs (Quinn \& Spreitzer, 1997). Meaningfulness is likely to be perceived in an organisational environment where the employees' well-being is embraced and their views are valued (Schnell et al., 2013). Employees who find meaning in their work have a sense of purpose, experience their job as important to them and are far less likely to leave their employer. Mining employees can find meaning in their job if they perceive that they are well taken care of.

\section{Correlation analysis - Employee empowerment on turnover intention}

Spearman's rank correlation coefficient was employed to answer this sub-research question. There was a weak, negative correlation between structural empowerment and turnover intention (rho $=-0.22, n=366, p<0.01$ ). This suggests that lower levels of structural empowerment are associated with increased turnover intention. Hence, a negative significant correlation exists. At the same time, there was a weak, negative correlation between psychological empowerment and turnover intention (rho = $-0.15, n=368, p<0.01$ ), with lower levels of psychological empowerment associated with increased turnover intention. Hence, a negative significant correlation exists. This suggests that when the employees experience disempowerment, they may consider leaving the organisation (Smith et al., 2012). Employee empowerment leads to job engagement (Jiang et al., 2019) and job satisfaction (Choi et al., 2016).
The employees in this organisation may have felt disempowered, subsequently disengaged in their jobs and decreased job satisfaction, hence the intention to leave. The problem with turnover intention is that it may cause employees to be less committed (Xiong \& Wen, 2020) to their work and, consequently, negatively impact their outputs (De Simone et al., 2018). In this way, these employees become a liability to the organisation (Jung, 2014; Xiong \& Wen, 2020). It can be suggested that if mine employees become less committed because they intend to leave the organisation, they are likely to display unsafe and counterproductive behaviours.

A positive correlation was established between structural empowerment and psychological empowerment ( $\mathrm{rho}=0.48$, $n=369, p<0.01$ ), with higher levels of structural empowerment leading to psychological empowerment. This finding is confirmed by the study of Laschinger et al. (2001). Similarly, Wagner (2010) found that there is a relationship between structural empowerment and psychological empowerment. This suggests that if employees perceive that they have structural empowerment, they consequently perceive that they are psychologically empowered. If structural empowerment avenues (support, resources, information and opportunities) are provided to the employees, this may lead to their perceiving psychological empowerment.

\section{Correlational analysis of work experience, structural empowerment, psychological empowerment and turnover intention}

There was a weak, positive correlation between work experience and psychological empowerment (rho $=0.14$, $n=365, p<0.01$ ). Employees with longer work experience presented with higher levels of psychological empowerment. Previous studies did not report on the correlation between work experience and psychological empowerment. A possible explanation for why the experienced employees perceived more psychological empowerment in this organisation is that, once again, they may have developed a healthy relationship with their supervisors and colleagues over the years. Experienced employees may have pursued their jobs long enough for them to have become part of their lives. There was no significant correlation amongst work experience, structural empowerment and turnover intention.

\section{Independent-samples $t$-test: Gender on structural empowerment, psychological empowerment and turnover intention}

An independent samples $t$-test was conducted to compare the scores for structural empowerment, psychological empowerment and turnover intention for males and females, and addresses the sub-research question to investigate biographical differences. There was no significant difference in the scores for males and females regarding structural empowerment. To a large extent, the gender of the employees in this mine did not influence how these employees perceived access to formal and informal power. This sheds some light 
on the progress of women empowerment at this particular mine and may suggest that both men and women in this mine have equal chances to acquire formal and informal power.

There was, however, a significant difference in the scores for males and females regarding psychological empowerment. A medium effect size of 0.30 was computed. This difference sheds some light on how males and females perceive psychological empowerment in this organisation. Females perceived less psychological empowerment than males. On the contrary, Boudrias, Gaudreau and Laschinger (2004) found that psychological empowerment could be assumed to be the same across the male and female employees, although the study was conducted in a different sector. This finding can be attributed to the difficult (Chimamise et al., 2013; Mclean, 2012) and dangerous conditions in which the mining employees work (Amponsah-Tawiah et al., 2013; Kasap, 2011; Paul \& Maiti, 2007). These conditions may have resulted in female employees' perceiving relatively lower psychological empowerment in their jobs than did the men. This can be attributed to the fact that mining organisations are traditionally a male-dominated working environment (Botha \& Cronje, 2015).

There was no significant difference in the scores for males and females regarding turnover intention. The chances that the female employees intended to resign were almost equal to those of the male employees. On the contrary, Nie et al. (2018) found that the availability of equal career opportunities across all genders may prevent turnover intention of female employees. However, career opportunities acted as a moderating variable. One would have expected the female employees in this organisation to experience higher turnover intention levels because they experienced less psychological empowerment in their jobs. However, this mine is not the case, which can be attributed to today's business environment characterised by fluctuating markets and organisational restructurings (Dhanpat \& Parumasur, 2014). The employees (both male and female) in this organisation may have been bothered by the prevalent retrenchments in the mining industry (Marais et al., 2018), hence no correlation existed between gender and turnover intention.

\section{Limitations of the study}

The shortcoming that can be associated with a crosssectional approach is its inability to measure change in a phenomenon over a period of time (Saunders et al., 2016). Because of the sensitivity of some variables, some respondents may have provided socially desirable responses. Quantitative data were collected because the researcher was looking for causal relationships; this type of study is unable to provide a narrative as to why the respondents behaved in a certain way. The study was conducted in one mining organisation, hence, it cannot be generalised to other industries, and the results should, therefore, be interpreted with caution.

\section{Recommendations and managerial implications}

In light of the excessive costs associated with turnover, turnover intention should be avoided by all means. When employees are empowered, their turnover intention tends to decrease. Human resource (HR) managers need to be innovative in ensuring that employees are empowered in terms of structural and psychological empowerment. Although structural empowerment does not predict turnover intention, employees must be structurally empowered. Such avenues should be provided by the organisation through HRs and employees direct line managers. Although the employees in this organisation acknowledged that they had some access to empowerment avenues such as resources, support, information and opportunity, these did not predict turnover intention. This has serious implications to the HR managers of this mining organisation to focus on formal power and informal power and not lose sight on the aforementioned empowerment dimensions. Human resource managers would need to investigate how they could help employees to find meaning in their jobs. Cultivating meaning through various HR interventions will assist in reducing turnover intention. Employees at the mine do possess informal power, and HR can enhance this by providing opportunities for collaboration between subordinates, peers and line managers. Employees perceived that they were not afforded opportunities to make decisions on their own. This is understandable, especially for the lower-level employees, as they may not have absolute autonomy. However, because of the risky nature of the underground workplace, it would be recommended that Section 23 of the Mine Health and Safety Act (that empowers the employees to withdraw from unsafe places; Republic of South Africa, 1996) be emphasised on these employees so that they know that they can at least make their own decisions regarding their safety. Human resource managers in the organisation where the study was conducted would need to cautiously monitor employees who have informal power, as this study has revealed that they may be more inclined to leave the organisation.

Employees may feel empowered (psychological or structural) in their work. Based on their empowerment levels, it may lead to employees leaving as such organisations need to find solutions and HR to provide opportunities and resources for employees to feel empowered.

\section{Recommendations for future research}

The insights provided by the current study can assist future researchers in considering alternate measures for structural empowerment and psychological empowerment. This recommendation is motivated by the fact that only three contributed significantly to the model out of the original 10 empowerment variables investigated. These variables 
were formal power, informal power and meaning. This may have something to do with the nature and the culture of the mining industry, and hence, it may be beneficial to test alternate measures. Alternatively, the same measure can be used in a larger sample and different work settings. A mixed-method approach may also be considered to obtain qualitative insights that could be used for narrative purposes. It may be beneficial to conduct the study in more than one mining organisation to enable the generalisation of the results. A longitudinal study would assist in measuring change in the phenomenon over a period of time and provide insights into the fluctuations of employee empowerment.

\section{Conclusion}

The employees who perceived having informal power were more likely to think of leaving the organisation. In terms of psychological empowerment, the logistic regression results revealed that employees who perceived less meaning in their work were more likely to leave the organisation than those who did not find meaning. Employees at the mine who perceived having structural empowerment had a decreased intention to leave. Employees who possessed higher levels of psychological empowerment exhibited a decreased intention to leave. Older employees showed higher levels of psychological empowerment. There was a weak, positive correlation between work experience and psychological empowerment. Higher levels of psychological empowerment were associated with employees with longer work experience. There was no significant difference in the scores for males and females regarding structural empowerment and turnover intention. There was, however, a significant difference in the scores for males and females regarding psychological empowerment.

\section{Acknowledgements}

Special thanks to Ms Juliana van Staden from UJ Statistical Consultation Services Division (Statcon) for assistance with the statistical analysis. A special thanks to Mr Kevin Walker for his language editing services.

\section{Competing interests}

The authors declare that they have no financial or personal interests that may have improperly influenced them in writing this article.

\section{Author's contributions}

N.D. was the supervisor of the study and was responsible for consolidating and preparing the article for publication. K.N was responsible for assisting in preparing the article for submission from his master's dissertation.

\section{Funding information}

This research received no specific grant from any funding agency in the public, commercial or not-for-profit sectors.

\section{Data availability}

Data sharing is not applicable to this article as no new data were created or analysed in this study.

\section{Disclaimer}

The views and opinions expressed in this article are those of the authors and do not necessarily reflect the view of my employer.

\section{References}

Aggarwal, A., Dhaliwal, R.S., \& Nobi, K. (2018). Impact of structural empowerment on organizational commitment: The mediating role of women's psychological empowerment. Vision, 22(3), 284-294. https://doi.org/10.1177/0972262918 786049

Amponsah-Tawiah, K., Leka, S, Jain, A., Hollis, D., \& Cox, T. (2013). The impact of physical and psychosocial risks on employee well-being and quality of life: The case of the mining industry in Ghana. Safety Science, 65(2014), 28-35. https://doi. org/10.1016/j.ssci.2013.12.002

Amponsah-Tawiah, K., Ntow, M.A.O., \& Mensah, J. (2016). Occupational health and safety management and turnover intention in the Ghanaian mining sector. Safety and Health at Work, 7(2016), 12-17. https://doi.org/10.1016/j.shaw.2015.08.002

Bester, J., Stander, M.W., \& Van Zyl, L.E. (2015). Leadership empowering behaviour, psychological empowerment, organisational citizenship behaviours and turnover intention in a manufacturing division. South African Journal of Industrial Psychology, 41(1), 1-14. https://doi.org/10.4102/sajip.v41i1.1215

Botha, D., \& Cronje, F. (2015) Women in mining: A conceptual framework for gender issues in the South African mining sector. South African Journal of Labour Relations, 39(1), 10-37. https://doi.org/10.25159/2520-3223/5880

Boudrias, J.S., Gaudreau, P., \& Laschinger, H.K.S. (2004). Testing the structure of psychological empowerment: Does gender make a difference? Educational and Psychological Measurement, 64(5), 861-877. https://doi.org/10.1177/ 0013164404264840

Brewer, C.S., \& Kovner, C.T. (2014). Intersection of migration and turnover theories: What can we learn? Nursing Outlook, 62(1), 29-38. https://doi.org/10.1016/j. outlook.2013.09.002

Brien, A., Thomas, N., \& Hussein, A.S. (2015). Turnover intention and commitment as part of organisational social capital in the hotel industry. Journal of Human Resources in Hospitality and Tourism, 14, 357-381. https://doi.org/10.1080/1533 2845.2015.1008385

Brown, A., Susomrith, P., Sitlington, H., \& Scott, G. (2014). Determinants of employeeturnover intentions in atypical employment: the FIFO mining industry in Western Australia. Australian Bulletin of Labour, 40(2), 116-137.

Buta, S., \& Burciu, A. (2014). The impact of the business environment on the shaping of an organization chart. The USV Annals of Economics and Public Administration, 14(1[19]), 128-137.

Chaskalson, R. (2016). The road to Marikana in South Africa's platinum industry, 1994-2012. Journal of Southern African Studies, 42(5), 857-873. https://doi.org/ 10.1080/03057070.2016.1211807

Chen, H., Chen, F., Zhu, D., Qi, H., \& Long, R. (2015). Burnout in Chinese coal mine safety supervision. Energy Policy, 85, 22-31. https://doi.org/10.1016/j.enpol.2015.05.007

Chimamise, C., Gombe, N.T., Tshimanga, M., Chadambuka, A., Shambira, G., \& Chimusoro, A. (2013). Factors associated with severe occupational injuries at mining company in Zimbabwe, 2010: A cross-sectional study. Pan African Medical Journal, 14(1), 1-5. https://doi.org/10.11604/pamj.2013.14.5.1148

Choi, S.L., Goh, C.F., Adam, M.B.H., \& Tan, O.K. (2016). Transformational leadership, empowerment, and job satisfaction: The mediating role of employee empowerment. Human Resources for Health, 14(73), 1-14. https://doi. org/10.1186/s12960-016-0171-2

Choo, C. (1996). The knowing organization: How organizations use information to construct meaning, create knowledge and make decisions. International Journal of Information Management, 16(5), 329-340. https://doi.org/10.1016/0268of Information Man

Conger, J.A., \& Kanungo, R.N. (1988). The empowerment process: Integrating theory and practice. Academy of Management Review, 13(3), 471-482. https://doi. org/10.5465/amr.1988.4306983

De Simone, S., Planta, A., \& Cicotto, G. (2018). The role of job satisfaction, work engagement, self-efficacy and agentic capacities on nurses' turnover intention and patient satisfaction. Applied Nursing Research, 39, 130-140. https://doi. org/10.1016/j.apnr.2017.11.004

Dhanpat, N., \& Parumasur, S.B. (2014). Re-establishing the psychological contract as a precursor to employee retention. Problems and Perspectives in Management, 12(4), 78-90.

Eriksson, E., \& Engstrom, M. (2018). Internationally educated nurses' descriptions of their access to structural empowerment while working in another country's health care context. Journal of Nursing Management, 26(7), 866-873. https://doi. org/10.1111/jonm.12617 
Ertürk, A., \& Vurgun, L. (2015). Retention of IT professionals: Examining the influence of empowerment, social exchange, and trust. Journal of Business Research, 68, of empowerment, social exchange, and trust. Journal

Fasanmi, S.S., \& Ago-Iwoye. (2018). Effects of commitment, justice and empowerment on organisational citizenship behaviour and turnover intent among Nigerian bankers. An International Journal, 26(1), 16-44.

Ferede, A., Kibret, G.D., Million, Y., Simeneh, M.M., Belay, Y.A., \& Hailemariam, D. (2018). Magnitude of turnover intention and associated factors among health professionals working in public health institutions of North Shoa Zone, Amhara Region, Ethiopia. BioMed Research International, 2018, 1-9. https://doi. org $/ 10.1155 / 2018 / 3165379$

Jiang, W., Wang, L., Chu, Z., \& Zheng, C. (2019). Does leader turnover intention hinde team innovation performance? The roles of leader self-sacrificial behavior and empathic concern. Journal of Business Research, 104, 261-270. https://doi. org/10.1016/j.jbusres.2019.07.013

Jung, C.S. (2014). Why are goals important in the public sector? Exploring the benefits of goal clarity for reducing turnover intention. Journal of Public Administration Research and Theory, 24(1), 209-234. https://doi.org/10.1093/jopart/mus058

Kane-Berman, J. (2018, February 10). The impact of mining on the South African economy and living standards. The Federation for a Sustainable Development Retrieved from http://fse.org.za/index.php/item/593-the-impact-of-mining-onthe-south-african-economy-and-living-standards

Kang, H.J.A., Kim, W.G., Choi, H.M., \& Li, Y. (2020). How to fuel employees' prosocial behavior in the hotel service encounter. International Journal of Hospitality Management, 75, 1-10. https://doi.org/10.1016/j.ijhm.2019.102333

Kanter, R.M. (1993). Men and women of the corporation (2nd ed.). New York: Basic Books.

Kanter, R.M. (1977). Men and women of the corporation (1st ed.). United States of America: Basic Books.

Kasap, Y. (2011). The effect of work accidents on the efficiency of production in the coal sector, South African Journal of Science, 107(5), 1-9. https://doi.org/10.4102/ sajs.v107i5/6.513

Kim, S.Y., \& Fernandez, S. (2017). Employee empowerment and turnover intention in the U.S. federal bureaucracy. American Review of Public Administration, 47(1) 4-22. https://doi.org/10.1177/0275074015583712

Kostopoulos, I. (2019). Do empowered front-line employees perform better? A non linear approach and the role of service complexity. European Management Review, 16(2), 229-242. https://doi.org/10.1111/emre.12153

Laschinger, H.K.S. (2012). Conditions for work effectiveness questionnaire I and II. Retrieved from https://www.uwo.ca/fhs/hkl/cweq.html

Laschinger, H.K.S., Finegan, J., Shamian, J., \& Wilk, P. (2001). Impact of structural and psychological empowerment on job strain in nursing work settings: Expanding
Kanter's model. Journal of Nursing Administration, 31(5), 260-272. https://doi. Kanter's model. Journal of Nursing Administrc
org/10.1097/00005110-200105000-00006

Laschinger, H.K.S., Sabiston, J.A., \& Kutszcher, L. (1997). Empowerment and staff nurse decision involvement in nursing work environments: Testing Kanter's theory of decision involvement in nursing work environments: Testing Kanter's theory of
structural power in organizations. Research in Nursing and Health, 20, 341-352. structural power in organizations. Research in Nursing and Health, 20, 341-352. https://doi.org/10.1
NUR7\%3E3.0.CO;2-G

Lu, C.Q., Sun, J.W., \& Du, D.Y. (2016). The relationships between employability emotional exhaustion, and turnover intention: The moderation of perceived career opportunity. Journal of Career Development, 43(1), 1-15. https://doi. career opportunity. Journal of Care
org/10.1177/0894845315576372

Mancini, L., \& Sala, S. (2018). Social impact assessment in the mining sector: Review and comparison of indicators frameworks. Resources Policy, 57, 98-111. https://

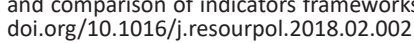

Mahmood, A., \& Sahar, A. (2017). Impact of psychological empowerment and perceived career support on employee work engagement with the mediating role of affective commitment. Pakistan Journal of Commerce and Social Sciences, 11(3), 1084-1099. https://doi.org/10.1021/acsnano.5b04612

Marais, L., Van Rooyen, D., Burger, P., Lenka, M., Cloete, J., Denoon-Stevens, S. ... Riet, J. (2018). The background to the Postmasburg study. In P. Burger, L. Marais, \& D. Van Rooyen (Eds.), Mining and community in South Africa: From small town to iron town. London and New York: Routledge.

Masia, U., \& Pienaar, J. (2011). Unravelling safety compliance in the mining industry: Examining the role of work stress, job insecurity, satisfaction and commitment as antecedents. South African Journal of Industrial Psychology, 37(1), 1-10. https:// doi.org/10.4102/sajip.v37i1.937

Mclean, K.N. (2012). Mental health and well-being in resident mine workers: Out of the FIFO box. Australian Journal of Rural Health, 20(3), 126-130. https://doi. org/10.1111/j.1440-1584.2012.01267.x

Menon, S.T., \& Vos, B. (2007). Psychological empowerment in the South African military: The generalisability of Menon's Scale. South African Journal of Industria Psychology, 33(2), 1-6. https://doi.org/10.4102/sajip.v33i2.371

Meyer, J.P., \& Tett, R.P. (1993). Job satisfaction, organisational commitment, turnover intention, and turnover: Path analyses based on meta-analytical findings. Personnel Psychology, 46, 259-293. https://doi.org/10.1111/j.1744-6570.1993. tb00874.x

Mikuljevi, M. (2013). New trends in employee education and training: The learning organisation. Journal of Labour and Social Affairs in Eastern Europe, 16(4) 467-479. https://doi.org/10.5771/1435-2869-2013-4-467

Mine Health and Safety Act, 1996 (Act No. 29 of 1996) and Regulations. (2018). Retrieved July 4, 2020, from https://www.mhsc.org.za/sites/default/files/public/ legislation_document/MineHealthandSafetyAct29of1996andRegulations FinalBooklet.pdf
Minerals council South Africa's position in advance of South Africa's budget statement. (2020). Retrieved April 1, 2020, from https://www.mineralscouncil.org.za/industrynews/publications/position-papers/send/37-position-papers/888-mineralscouncil-south-africa-s-position-in-advance-of-sa-s-budget-statement \&cd=1\&hl =en\&ct=clnk\&g|=za

Mościcka-Teske, A., Sadłowska-Wrzesińska, J., Najder, A., \& Butlewski, M. (2019). The relationship between psychosocial risks and occupational functioning among relationship between psychosocial risks and occupational functioning among miners. International Journal of Occupational Medicine and Envin
Health, 32(1), 87-98. https://doi.org/10.13075/ijomeh.1896.01162

Motebele, M.M., \& Mbohwa, C. (2013). Employee empowerment to improve organizational effectiveness at South African universities. World Academy of Science, Engineering and Technology, 83(2013), 893-899.

Neingo, P.N., \& Tholana, T. (2016). Trends in productivity in the South African gold mining industry. Journal of the Southern African Institute of Mining and Metallurgy, 116(3), 283-290. https://doi.org/10.17159/2411-9717/2016/v116n3a10

Nie, D., Lamsa, A.-M., \& Pucetaite, R. (2018). Effects of responsible human resource management practices on female employees' turnover intentions. A European Review, 27(1), 29-41. https://doi.org/10.1111/beer.12165

Nielsen, K., Nielsen, M.B., Ogbonnaya, C., \& Känsälä, M. (2017). Workplace resources to improve both employee well-being and performance: A systematic review and meta-analysis. Work \& Stress, 31(2), 101-120. https://doi.org/10.1080/0267 8373.2017.1304463

Pallant, J., (2010). SPSS survival manual: A step by step guide to data analysis using the SPSS program (6th ed.). New York: McGraw Hill.

Pallant, J. (2016). SPSS survival manual: A step by step guide to data analysis using IBM SPSS (6th ed.). New York, NY: Open University Press.

Parker, S.L., Jimmieson, N.L., \& Amiot, C.E. (2010). Self-determination as a moderator of demands and control: Implications for employee strain and engagement. Journal of Vocational Behavior, 76(1), 52-67. https://doi.org/10.1016/j. jvb.2009.06.010

Paul, P.S., \& Maiti, J. (2007). The role of behavioral factors on safety management in underground mines. Safety Science, 45(4), 449-471. https://doi.org/10.1016/j. ssci.2006.07.006

Paynton, T. (2008). The informal power of nurses for promoting patient care. OJIN: The Online Journal of Issues in Nursing, 14, 1-9.

Quinn, R.E., \& Spreitzer, G.M. (1997). Road to empowerment: Seven questions every leader should consider. IEEE Engineering Management Review, 27(2), 21-28. https://doi.org/10.1016/s0090-2616(97)90004-8

Republic of South Africa. (1996). Mine Health and Safety Act (no. 29 of 1996).

Republic of South Africa. (2020). Minerals council South Africa's position in advance of South Africa's budget statement.

Rogers, K.S. (2016). The role of organisational learning culture and psychological empowerment in reducing turnover intention and enhancing citizenship behavior. The Learning Organisation, 23(2), 156-169. https://doi.org/10.1108/TLO-052013-0024

Saunders, M., Lewis, P., \& Thornhill, A. (2016). Research methods for business students (7th ed.). Harlow: Pearson Education Limited.

Schnell, T., Höge, T., \& Pollet, E. (2013). Predicting meaning in work: Theory, data, implications. The Journal of Positive Psychology, 8(6), 543-554. https://doi. org/10.1080/17439760.2013.830763

Seibert, S.E., Silver, S.R., \& Randolph, W.A. (2004). Taking empowerment to the next level: A multiple-level model of empowerment, performance, and satisfaction. Academy of Management Journal, 47(3), 332-349. https://doi.org/10.2307/20159585

Sjoberg, A., \& Sverke, M. (2000). The interactive effect of job involvement and organisational commitment on job turnover revisited: A note on the mediating role of turnover intention. Scandinavian Journal of Psychology, 41(3), 247-252. https://doi.org/10.1111/1467-9450.00194

Smith, T., Capitulo, K.L., Quinn Griffin, M.T., \& Fitzpatrick, J.J. (2012). Structural empowerment and anticipated turnover among behavioural health nurses. Journal of Nursing Management, 20(5), 679-684. https://doi.org/10.1111/ j.1365-2834.2012.01384.x

Stander, M.W., \& Rothmann, S. (2010). Psychological empowerment, job insecurity and employee engagement. SA Journal of Industrial Psychology, 36(1), 1-8 https://doi.org/10.4102/sajip.v36i1.849

Spreitzer, G.M. (1995). Psychological empowerment in the workplace: Dimensions, measurement, and validation. Academy of Management Journal, 38(5), 1442-1435. https://doi.org/10.5465/256865

Spreitzer, G.M., De Janasz, S.C., \& Quinn, R.E. (1999). Empowered to lead: The role of psychological empowerment in leadership. Journal of Organisational Behaviour, 20,511-526. https://doi.org/10.1002/(SICI)1099-1379(199907)20:4\%3C511::AID JOB900\%3E3.0.CO;2-L

Spreitzer, G.M., \& Doneson, D. (2005). Musings on the past and future of employee empowerment. Handbook of organizational development, 4, 5-10.

Stander, M.W., \& Rothmann, S. (2009). Psychological empowerment of employees in selected organisations in South Africa. South African Journal of Industria Psychology, 35(1), 196-203. https://doi.org/10.4102/sajip.v35i1.466

Taylor, M.S., Audia, G., \& Gupta, A.K. (1996). The effect of lengthening job tenure on managers' organizational commitment and turnover. Organization Science, 7(6), 632-648. https://doi.org/10.1287/orsc.7.6.632

Thomas, W.T., \& Veldhouse, B.A. (1990). Cognitive elements of empowerment: An 'interpretive' model of intrinsic task motivation. Academy of Management Review, 15(4), 666-681. https://doi.org/10.5465/amr.1990.4310926 
Valcour, M., Ollier-Malaterre, A., Matz-Costa, C., Pitt-Catsouphes, M., \& Brown, M (2011). Influences on employee perceptions of organizational work - Life support:
Signals and resources. Journal of Vocational Behavior, 79(2), 588-595. https://doi. org/10.1016/j.jvb.2011.02.002

Vandenberg, R.J., \& Scarpello, V. (1990). The matching model: An examination of the processes underlying realistic job previews. Journal of Applied Psychology, 75(1), 60-67. https://doi.org/10.1037/0021-9010.75.1.60

Van Schalkwyk, S., Du Toit, D.H., Bothma, A.S., \& Rothmann, S. (2010). Job insecurity, leadership empowerment behaviour, employee engagement and intention to leave in a petrochemical laboratory. South African Journal of Human Resource Management, 8(1), 1-7. https://doi.org/10.4102/sajhrm.v8i1.234

Van Zyl, L.E. (2015). Power and politics. In S.P. Robbins, A. Odendaal, \& G. Roodt (Eds.) Organizational behaviour: Global and Southern African perspectives (3rd ed.). South Africa: Pearson Education Southern Africa.

Van Zyl, L.E. (2016). Power and politics. In R. Silvia (Ed.), Global and Southern African perspectives (3rd ed.). Cape Town: Pearson South Africa.
Vijayabanu, C., \& Therasa, C. (2016). The leveraging effect of supervisory competencies towards the performance in Indian manufacturing group: A structural equation modelling approach. Journal of Organisational Transformation and Social Change 13(3), 220-234. https://doi.org/10.1080/14779633.2016.1237147

Wagner, J. (2010). The relationship between structural empowerment and psychological empowerment for nurses: A systematic review. Journal of Nursing Management, 18(4), 448-462. https://doi.org/10.1111/j.1365-2834.2010.01088.x

Xiong, R., \& Wen, Y. (2020). Employees' turnover intention and behavioral outcomes: The role of work engagement. Social Behavior and Personality, 48(1), 1-8. https:// doi.org/10.2224/sbp.8609

Yaldiz, L.M., Truxillo, D.M., Bodner, T., \& Hammer, L.B. (2020). Do resources matter for employee stress? It depends on how old you are. Journal of Vocational Behavior, 107, 182-194. https://doi.org/10.1016/j.jvb.2018.04.005

Young-Hyman, T. (2017). Cooperating without co-labouring: How formal organizational power moderates cross-functional interaction in project teams: Administrative Science Quarterly, 62(1), 179-214. https://doi.org/10.1177/000183921665509 